\title{
Entrepreneurship Training and Early Retirement: A Twin Muzzle Solution to Un-Employment in Africa
}

\author{
${ }^{1}$ Jacob M. Mbijjiwe , ${ }^{2}$ Catherine K. Kathure \\ ${ }^{I}$ PhD Research Scholar in Management, Osmania University, Hyderabad-India \\ ${ }^{2}$ Lecturer, Meru Technical Training Institute, Meru-Kenya
}

\begin{abstract}
To help ease the problem of un-employment in Africa, a study on the impact of entrepreneurial training and early retirement was carried out in a number of African countries. The study targeted what roles early retirement intervention and entrepreneurial training can do to help boost the percentage of employed population. The study focused on the analysis of un-employment levels, retirement age, demographic characteristics, investment levels among retirees of different ages, wage bills in the public service organizations, employee performance versus experience and a comparative study of those indices among the first world economies. Data was basically got from secondary sources except the data from Kenya, and analyzed by use percentages, time series, trends, ratios, correlation analysis and ANOVA. It was presented using population pyramids, bar charts, graphs, linear regression graphs and pie charts. The study revealed that these countries have a huge proportion of population being youthful, the government or public service is a major employer, there is a high rate of un-employment, there is poor investment patterns among those retiring at the normal retirement age, the public services are faced with huge wage bills, there is low correlation between experience and performance and there is a big difference between the demographic patterns of these countries and those of the western countries. The study suggests that:

- Early retirement programs should be rolled out to increase chances of more investment hence employment.

- Governments' intervention to fund the retirement programs because there are all the signs that the pension bodies may not be prepared with that.

- The retirees need to be taken through a thorough entrepreneurial training to ensure that their early retirement benefits are not used for basic consumption instead of investment.

- Proper and timely evaluation of the programs is done and corrective measures put in place early enough.

- Measure to increase entrepreneurial training in educational institutions and work places.

Keywords: Entrepreneurship, Training, Early Retirement, Youth Un-Employment, Investment
\end{abstract}

\section{Introduction}

Unemployment is a situation where people who are able to work and willing to work are not able to find jobs. In Africa unemployment can be displayed as total lack of work, seasonal layoffs, and technical adjustments in industry due to increased automation, lack of necessary skills by workers, racial discrimination and instabilities of the local economies. What makes it worse is the fact that it has targeted the youth more and therefore a very serious problem facing Africa.

In Africa unemployment problem has been made worse by the fact that the public service or the governments remain the main employers of the populace. Lack of government job condemns one to a life of poverty. In other words it means that the private sector has not grown at the expected pace to take up the excess workforce. Alternatives measures therefore need to be introduced to remedy the situation.

One of the likely alternatives is allowing public service employees to go for early retirement schemes on conditions that they have investment work plans to turn to. The second option would be to widen the scope and abilities of employees and college trainees by developing their entrepreneurial abilities to make them not only job seekers but job creators. Early retirement schemes will require change in some legislation so that they can access their dues and pensions earlier than usual. Entrepreneurial training should as a matter of fact be part of the retirement package conditions. Schools, colleges and universities curriculum need to be more enhanced in terms of entrepreneurial training.

\section{Problem Statement}

One of the problems of this research was based on the fact that, although unemployment is a common problem in Africa, there is a high percentage of youth who fall in that category. To share the problem evenly there is need to get the youth in gainful employment to avoid youth related social, economic and political problems. 
Another disturbing trend is the fact that African countries are raising retirement ages of civil servants to the levels of the developed world even while it is very clear that the demographic realities are quite different. This automatically prolongs the waiting time for the youth queuing for employment.

A comparative look at how well retirees invest based on whether one retires early or takes normal retirement makes another research problem. While early retirees have to a substantial degree succeeded in private enterprise, it has not been the case for late retirees or those who take normal retirement.

A look at the public wage bill reveals that the senior employees earn substantially too high salary that can as well employ more youthful or new employees. A part from wage bill, the aged employees are also more costly in terms of medical expenses and lost time.

Lack of substantial entrepreneurial training in the schools, colleges, universities and retirement programs is another problem of this research. More needs to be done in terms entrepreneurial training.

\section{Related Research Focus}

This section gives a focus on what other researchers have unearthed on the unemployment problem and how early retirement initiatives and entrepreneurial training have been used to some success towards the reduction of the problem.

That Africa is the only continent today with an increasing youthful population is not in doubt as shown by a UN (2005) report.

This report is well supported by the ILO (2012) report titled Global employment Trends reveal that nearly 75 million youth are unemployed around the world with Africa having a substantial proportion. To make it worse Manpower group (2012) in their research on youth employment challenge and solutions reveal that labor force participation for the youth has been declining from 53.8\% in 1998 to $48.8 \%$ in 2011 . The report finally concludes the youth lack networks and information, relevant skills and requisite experience needed for winning competitive job positions. This implies the youth are continuously being cut off the areas of opportunities.

Ukpere (2011) in his research paper on Globalisation and the challenges of unemployment, income inequality and poverty in Africa finds that Africa, under the challenge posed by the global economies suffers job terminations, wage reductions, technological displacements and labor immobility all which fuel the unemployment problem. He suggests local African solutions to African problems rather than borrowing incompatible solutions. He singles out strengthening the human resource base of the local people to help identify the salient problems and their most apt solutions.

The Ministry of Foreign Affairs-Denmark, in their paper, Realising the Potential of African Youth, state that the African youth lack jobs, resources, knowledge and education and hence are boxed out of the opportunities for growth. The paper reminds Africa that the agriculture sector is hardly expanding despite the huge investment. The paper recommends a demand driven education that targets more productive employment and private sector development. A similar scenario is noticed in India as research by Mahendra and Venkatanarayana (2011) indicates that the youth age bracket of 15-24 years in India has increased two folds in the last ten years and they recommend that private sector growth and skills development initiatives are necessary to ensure that these youth end up in gainful employment.

Towards entrepreneurial training, Botha (2006) and colleagues, in their study on women entrepreneurship in South Africa sampled 180 women entrepreneurs from different provinces of South Africa and realized there is a marked improvement in entrepreneurial characteristics, entrepreneurial orientation, business knowledge and entrepreneurial business skills and a significant change in factors like business systems and strategies, financial indicators and change orientation once one is taken through entrepreneurial tutorage. This is highly collaborated by Ndedi (2009) in his study on entrepreneurship training and job creation in South Africa, he found out that, entrepreneurship training drives innovation, generates output, improves incomes and creates jobs. In addition it improves welfare, gives socio-economic empowerment and increases esteem and self confidence of the citizenly. He recommends that entrepreneurship training should be introduced in all levels of study and well integrated in the tertiary institutions programs and higher learning institutions.

For growth of entrepreneurship in any economy, the role of institutions is very key. As Emaad Muhanna (2007) puts it in his paper, "Conceptual analyses of the determinants of entrepreneurship", the educational, economic, political and legal institutions foster or restrict entrepreneurship in different countries and at various times. It is therefore very vital that such retirement and entrepreneurial programs get the necessary institutional support from the various institutions.

An SBP paper (2009) Boosting youth employment through entrepreneurship in South Africa suggested that other than funding youth groups, there should be trainings regarding the concepts and principles of entrepreneurship and business to youth and the promotion of a wider and more flexible range of learning pathways, through further education and vocational training, and the development of business skills, incubation 
and mentoring of budding entrepreneurs in high growth industries. They potentially extend to working with schools to provide young people with the knowledge and skills that foster an entrepreneurial culture.

Early retirement comes up as the controversial second barrel to unemployment problem. Banks, Blundell, Bozio and Emmerson (2008), in their analysis of the JRS-Job Release Scheme in the United Kingdom found no tangible evidence to support the idea that retirement of the old reduces unemployment by taking in the youthful employees in that what it only did is to get the aged out of the roll of the unemployed. Their research fails and differs with this research in that it fails to see the point that the old are simply not going home but investing their gratuities and pensions in businesses after going through entrepreneurial training.

A study by Tishman, Van Looy, and Bruyère (2012) on employer strategies for responding to an aging workforce in the U.S. realized that managers have negative feelings about the old workers like inflexibility, unwillingness or inability to adapt to new technology, lack of aggression, resistance to change, complacency, and the presence of physical limitations that increase the cost of health insurance. Such workers can still be retained in the developed economies because of the aging population, but should this also be a case for African states teeming with the problem of a bloated youthful population? This study is highly collaborated by Daniel Hallberg (2011) in his study titled, Is Early Retirement Encouraged by the Employer? He finally concludes workers productivity diminishes beyond the age of 50 years and their expense in wage and non-wage costs increase. These views are shared by Chalmers and Norris (2001) and Munjuri (2011) who, in her a study, A Survey of the Criteria Used by Commercial Banks in Kenya to Determine Employees to retrench, realized that Seniority, employee productivity, incapability and a early retirement scheme are used to lay off workers. The question therefore posed is; why is it that the same criteria can not apply in the public sector?

It is coming out clearly that scholars have realized that the African unemployment problem requires capacity building of people on entrepreneurial skills, give a chance to try out their skills on jobs and let the older employees invest their earning and in turn employ more people. The developed world is different in that it is at a phase of aging population.

\section{General Background of Research}

\section{Methodology of research}

The design employed in this research is descriptive. It assesses the working age population in Africa and describes their characteristics. It employs articles and secondary data review technique and complements it with survey approach done in Kenya as a case to gather relevant information. The survey became necessary to test the validity of the secondary data so collected.

\section{Research Population}

The working age population made up the population of this study where working age means those in public service, business, employed in private organizations or students in the age above 18 years.

\section{Research Sample}

A sample of 649 respondents was randomly picked from all the Provinces of Kenya and all the sectors to give their views on the study area as a representative case for Africa. A target sample size of 100 respondents was targeted from every province but some were discarded due to lack of completeness and inconsistent information.

\section{Sampling Design}

The respondents were randomly sampled on convenience basis with a bias towards those who were over 18 years of age since it is the legal working age in Kenya. To ensure better representation different research assistants were used to collect data from the respondents by administering questionnaires.

\section{Research Instruments}

Various instruments were required namely; A questionnaire with 28 items which covered Youth and employment, retirees and investment, cost of employees and entrepreneurial training was used to collect data from respondents.

Of necessity also were, introduction letters and survey guides.

Table 1: Case Processing Summary

\begin{tabular}{|c|c|c|c|}
\hline & & $\mathrm{N}$ & $\%$ \\
\hline \multirow[t]{2}{*}{ Cases } & Valid & 649 & 100.0 \\
\hline & Excluded(a) & 0 & .0 \\
\hline
\end{tabular}


A Listwise deletion based on all variables in the procedure.

Table 2: Reliability Statistics

\begin{tabular}{|l|l|}
\hline Cronbach's Alpha & N of Items \\
\hline .712 & 28 \\
\hline
\end{tabular}

The questionnaire tested for reliability and a measure of $\mathbf{0 . 7 1 2}$ which passes it as a reliable instrument of data collection.

\section{Data Analysis and Presentation}

Data analysis was done using SPSS version 15. Analysis of secondary data was manually done. Data was presented using charts, tables, graphs and Population pyramids.

\section{Demographic facts about Africa: Youthful population}

\section{Results of Research}

Africa still stands out as the only continent with an increasing youthful population compared to the other continents and it is projected to have a bigger youth population than South Asia by 2050. This therefore is a real threat to livelihood in Africa because this youthful population must be engaged before they pick on negative aspects for their survival. It is unfortunate because the growth is not in tune with the economic growth of African states.

Fig 1: Trend of youth population in the world

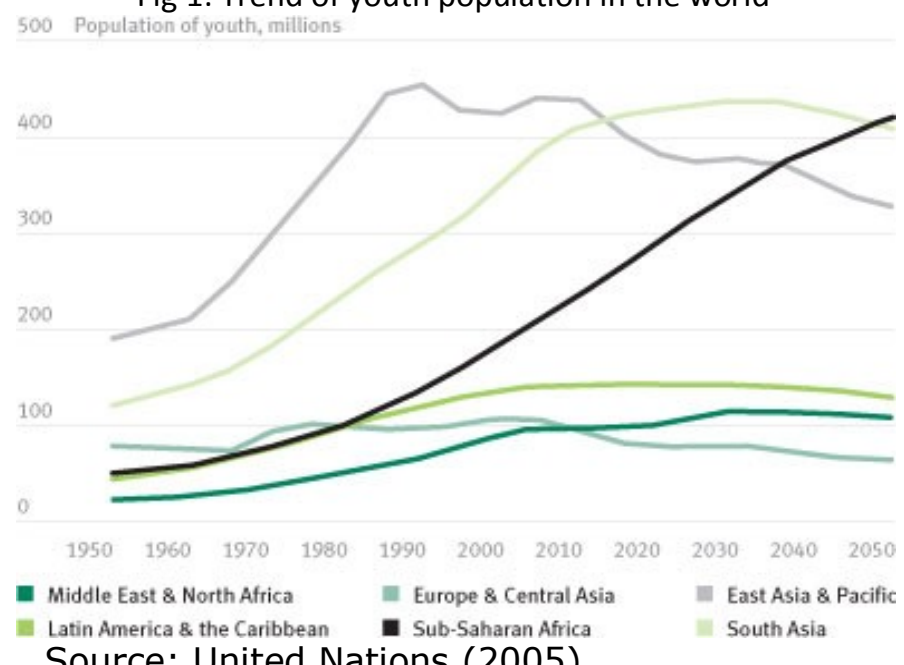

Source: United Nations (2005)

The population pyramids of the African states to date portray widened base and very thin at the top. This is a real contrast of what the fact is in the Western economies. The wide bases signify a huge percentage of the population is dependent on very few members of the population. It is therefore vital that the huge youthful population is turned to producers rather than consumers.

\section{Entrepreneurial Training handicaps}

Table 1: School system lacks coverage of entrepreneurial training

\begin{tabular}{|l|l|l|l|l|l|}
\hline \multicolumn{2}{|c|}{} & Frequency & Percent & Valid Percent & $\begin{array}{l}\text { Cumulative } \\
\text { Percent }\end{array}$ \\
\hline \multirow{4}{*}{ Valid } & Strongly disagree & 3 & .5 & .5 & .5 \\
\cline { 2 - 6 } & Disagree & 42 & 6.5 & 6.5 & 6.9 \\
\cline { 2 - 6 } & Neutral & 137 & 21.1 & 21.1 & 28.0 \\
\cline { 2 - 6 } & Agree & 375 & 57.8 & 57.8 & 85.8 \\
\cline { 2 - 6 } & Strongly agree & 92 & 14.2 & 14.2 & 100.0 \\
\cline { 2 - 6 } & Total & 649 & 100.0 & 100.0 & \\
\hline
\end{tabular}

From Table 1 above, $72 \%$ of the respondents were of clear opinion that the school system lacks entrepreneurial training. This is where the weakness starts. 
Table 2: University do not give much emphasis on entrepreneurship compared to technical areas.

\begin{tabular}{|l|l|l|l|l|l|}
\hline \multicolumn{2}{|c|}{} & Frequency & Percent & Valid Percent & $\begin{array}{l}\text { Cumulative } \\
\text { Percent }\end{array}$ \\
\hline \multirow{5}{*}{ Strongly disagree } & 1 & .2 & .2 & .2 \\
\cline { 2 - 7 } & Disagree & 15 & 2.3 & 2.3 & 2.5 \\
\cline { 2 - 7 } & Neutral & 58 & 8.9 & 8.9 & 11.4 \\
\cline { 2 - 7 } & Agree & 506 & 78.0 & 78.0 & 89.4 \\
\cline { 2 - 7 } & Strongly agree & 69 & 10.6 & 10.6 & 100.0 \\
\cline { 2 - 6 } & Total & 649 & 100.0 & 100.0 & \\
\hline
\end{tabular}

With the Universities it is even worse with close to $90 \%$ of the respondents having the opinion that Universities only concentrate on their technical and little emphasis to entrepreneurial training. It has an implication that university graduates will always go out looking for jobs rather apply their skills to be productive and therefore employers instead of employees.

This is further collaborated by Fig. 4 below which gives a comparative enrolment ratio in education worldwide. Sub-Saharan Africa has only about 5\% enrolled in tertiary institutions. This is a sad story because these are the economy drivers in the Western economies. The dismal figure in Africa means low investment and poor entrepreneurship.

Fig 4: Enrolment Ratio in Education

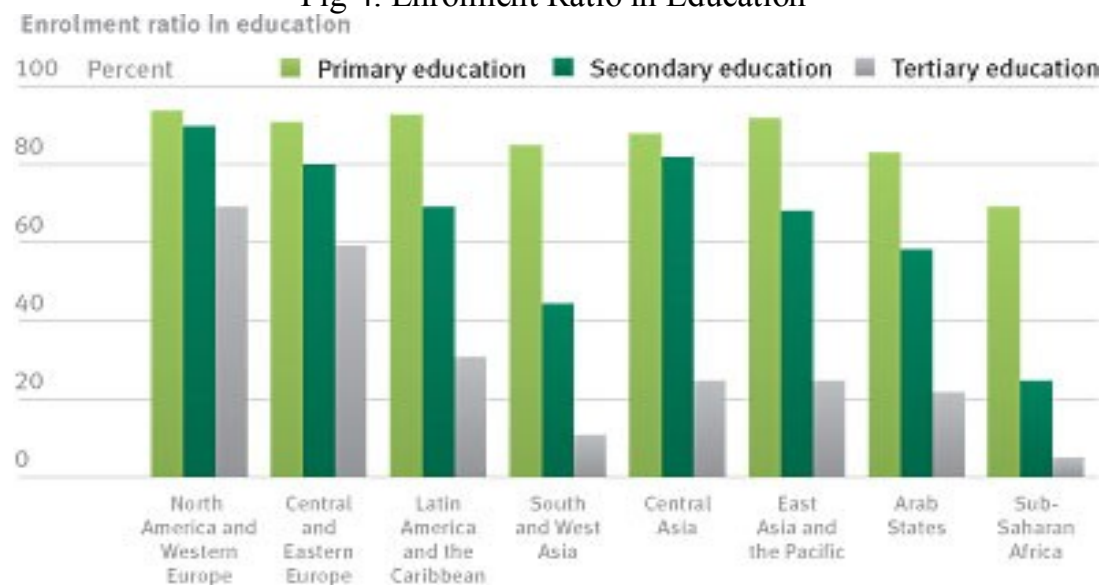

Source: Education for All Global Monitoring Report, UNESCO (2008)

\section{Cost of old Employees compared to young employees}

Table 3: Old employees are more costly to keep than young employees

\begin{tabular}{|l|l|l|l|l|l|}
\hline \multicolumn{2}{|c|}{} & Frequency & Percent & Valid Percent & $\begin{array}{l}\text { Cumulative } \\
\text { Percent }\end{array}$ \\
\hline \multirow{8}{*}{ Valid } & Strongly disagree & 10 & 1.5 & 1.5 & 1.5 \\
\cline { 2 - 6 } & Disagree & 32 & 4.9 & 4.9 & 6.5 \\
\cline { 2 - 6 } & Neutral & 33 & 5.1 & 5.1 & 11.6 \\
\cline { 2 - 6 } & Agree & 379 & 58.4 & 58.4 & 70.0 \\
\cline { 2 - 6 } & Strongly agree & 195 & 30.0 & 30.0 & 100.0 \\
\cline { 2 - 6 } & Total & 649 & 100.0 & 100.0 & \\
\hline
\end{tabular}

$88.4 \%$ of the respondents are of the opinion that it is more costly to keep old employees. 
Table 4: ANOVA test on relationship between age and cost of employees

\begin{tabular}{|l|l|l|l|l|l|}
\hline & $\begin{array}{l}\text { Sum of } \\
\text { Squares }\end{array}$ & df & Mean Square & F & Sig. \\
\hline Between Groups & 22.278 & 6 & 3.713 & 5.722 & .000 \\
\hline Within Groups & 416.598 & 642 & .649 & & \\
\hline Total & 438.875 & 648 & & & \\
\hline
\end{tabular}

On testing the hypotheses that, "there is no significant relationship between age and cost of employees" revealed an $\mathrm{F}$ value of 5.722 against a critical value of 2.1 , hence the hypotheses is rejected, implying there exists a significant relationship.

\section{Entrepreneurship among retirees}

Table 5: Late retires lack energy, interest and time to invest

\begin{tabular}{|l|l|l|l|l|l|}
\hline \multicolumn{2}{|c|}{} & Frequency & Percent & Valid Percent & $\begin{array}{l}\text { Cumulative } \\
\text { Percent }\end{array}$ \\
\hline \multirow{8}{*}{ Valid } & Strongly disagree & 21 & 3.2 & 3.2 & 3.2 \\
\cline { 2 - 6 } & Disagree & 199 & 30.7 & 30.7 & 33.9 \\
\cline { 2 - 6 } & Neutral & 28 & 4.3 & 4.3 & 38.2 \\
\cline { 2 - 6 } & Agree & 355 & 54.7 & 54.7 & 92.9 \\
\cline { 2 - 6 } & Strongly agree & 46 & 7.1 & 7.1 & 100.0 \\
\hline & Total & 649 & 100.0 & 100.0 & \\
\hline
\end{tabular}

On investment among late retirees, $61.8 \%$ were for the opinion that late retires lack the energy, the interest and time to invest.

Table 6: Early retirees have a higher drive to invest

\begin{tabular}{|l|l|l|l|l|l|}
\hline \multicolumn{2}{|c|}{} & Frequency & Percent & Valid Percent & $\begin{array}{l}\text { Cumulative } \\
\text { Percent }\end{array}$ \\
\hline \multirow{5}{*}{ Valid } & Disagree & 19 & 2.9 & 2.9 & 2.9 \\
\cline { 2 - 6 } & Neutral & 42 & 6.5 & 6.5 & 9.4 \\
\cline { 2 - 6 } & Agree & 377 & 58.1 & 58.1 & 67.5 \\
\cline { 2 - 6 } & Strongly agree & 211 & 32.5 & 32.5 & 100.0 \\
\cline { 2 - 6 } & Total & 649 & 100.0 & 100.0 & \\
\hline
\end{tabular}

On the other hand $90.6 \%$ of the respondents feel that those who retire early have a higher drive to invest.

Table 7: ANOVA on Relationship between Age and Investment

\begin{tabular}{|l|l|l|l|l|l|l|}
\hline \multicolumn{2}{|c|}{} & $\begin{array}{l}\text { Sum of } \\
\text { Squares }\end{array}$ & df & $\begin{array}{l}\text { Mean } \\
\text { Square }\end{array}$ & F & Sig. \\
\hline \multirow{2}{*}{$\begin{array}{l}\text { Late retires lack energy, } \\
\text { interest and time to invest }\end{array}$} & Between Groups & 82.155 & 6 & 13.693 & 13.034 & .000 \\
\cline { 2 - 8 } & Within Groups & 674.458 & 642 & 1.051 & & \\
\cline { 2 - 8 } $\begin{array}{l}\text { Early retirees have atal } \\
\text { higher drive to invest }\end{array}$ & Totween Groups & 10.660 & 6 & 1.777 & 3.908 & .001 \\
\cline { 2 - 8 } & Within Groups & 291.898 & 642 & .455 & & \\
\cline { 2 - 8 } & Total & 302.558 & 648 & & & \\
\end{tabular}

An ANOVA test on an hypotheses that "there is no significant relationship between age and investment" reveals $F$ values of 13.034 and 3.908 against a critical value of 2.1, implying that the hypotheses is rejected, hence there exist a significant relationship.

\section{Discussions}

After the review of other researchers work and analysis of the data of the current research a number of issues eventually are evident.

First is the fact the African countries have a huge youthful population that is steadily growing than nowhere else in the world. The population pyramids of Africa portray a wide base and very narrow top. It is worrying to realize that $54.4 \%$ of the respondents feel that the youth are social problems in Kenya while $52 \%$ of them have a feeling that the youth lack the basic job skills. This implies the future or demise of Africa lies within the youthful group. Many developed countries are increasing the retirement ages but it is obvious that such policy will never do any good to Africa.

On entrepreneurial training, all educational institutions in Kenya and Africa in general seem to have disregarded it to very alarming proportions. A huge $89.5 \%$ percent feel entrepreneurial training will reduce reliance on white collar jobs in Africa. Another 90.7\% feel that entrepreneurial training is needed as much as technical training in institutions. It is time the teachings shifted from the theoretical base they are to a more 
practical approach. Although many may argue that entrepreneurs are born, research has shown many have been made.

It is evident from the research findings that early retires have been more productive on retirement than old or those who retire at the normal age. To start with $85 \%$ of respondents feel that late retirees' pensions end up in the domestic consumption hence little investment value. On employment $65.8 \%$ feel that late retirees contribute little towards employment creation and $44 \%$ feel late retirees lack investment knowledge and skills. On investment $73.7 \%$ disagree that private enterprise in Kenya is risky while $65.3 \%$ feel there is a lot of areas for investment not yet captured and $54.1 \%$ feel the problem of poor investment is a result of lack of knowledge and skills. There is a feeling by $84.3 \%$ of the respondents that civil servants and other workers with a history of private enterprise should start such program to ensure it is successful. This is because they will build on their experience and knowledge base prior business ventures. On cost of employees it is cheaper to have young employees as compared to old ones. This is in terms of wage and non-wage costs. Such young employees are more productive as witnessed by $77.5 \%$ of the respondents. Absence from work on medical and personal engagements is higher among the older employees.

Therefore as much as old employees have the experience, expertise and keep the organizational memory it reaches a point where for their sake and the sake of the entire continent they need to be taken through early retirement programs and helped to fit and join the entrepreneurial world to create more jobs for the youthful population. What is very key is that they need to go through entrepreneurial training before they leave to venture into private practice.

It is very vital that future study is done on a practical project model that gives quantification of every item in financial terms. That is the cost in terms of retirement benefits is worked out and the resulting capital investment coupled with the financial returns from the employment that do result. When pension bodies are not able to give the financial returns to the retirees immediately the governments should be able to extend the same and follow up the pension bodies.

Sometimes such programs might have failed especially if retirement was not coupled with entrepreneurial training or entrepreneurial training is done and there is no source of capital to implement the programs since pension bodies may not give the gratuities immediately.

\section{Conclusions and Suggestions}

This paper makes a case for what many governments have shied off from doing; retiring people when strong enough and building confidence and skills of the youthful employees. Many African governments have jumped into raising retirement age just because it is being done in the developed world and also because they want to suspend the payment of pension dues for some time but they forget that the future problems will be tougher. They also forget that the earlier an employee retires, the lower the retirement package burden to the government. What is very clear today is most retirees, due to advanced age are retiring to idle life which in a flash invites unhealthy life and eventual death.

From the review of the research studies and the current research it is worth making the following conclusions;

- Unemployment in Africa is a social, economic and political problem that needs to be addressed by all means and in the shortest time possible.

- That the increase in retirement ages prevalent in the developed world has no room in Africa if we have to reduce the unemployment problem.

- Workers should be supported and encouraged to retire early and put their pensions and gratuities in investments other than domestic use.

- Younger employees are easier to manage, more productive and cheaper in terms of salary, pensions and health maintenance to organizations.

- Focus for early retirement should be directed more towards those who have had an earlier experience in private enterprise.

- The governments should try and reduce the wage bills by implementing early retirement schemes and the savings used to support the early retires towards their investment ventures and implement entrepreneurial training in institutions and work places.

- Entrepreneurial training for retirees is poorly done in the African countries. This, together with introducing entrepreneurial training in education institutions is the solution to the huge un-employment prevalent in Africa today.

- Educational institutions should be taken as bases where entrepreneurial training begins since at every level of education there are drop-outs in Africa. Such drop-outs should always be armed with knowledge and skills to implement whatever plans they might have.

- Legislations should be put in place to govern early retirement schemes and entrepreneurial training especially on the timings of the pensions release by pension bodies. Currently one can only retire with 
pensions after reaching a certain age. This should be done away with so that every employee is liable to get their pensions. This will push and transform more employees to being employers.

- There is need for governments funding programs that can strengthen the early retirees' investment projects to give guidance and evaluation to avoid failure. It is evident that pension bodies have misused or poorly invested the employees' contributions so that they do not get them at the time they need the funds.

- For success of such programs in Africa, they need to enjoy political good will and protection. This is because politics has interfered and killed even very good intentions, therefore the political class has by all means, to be bought into the plan.

Notable quote: "I do not believe we can repair the basic fabric of society until people who are willing to work have work. Work organizes life; it gives structures and discipline to life". BILL CLINTON-Former President of U.S.A.

\section{References:}

[1]. Banks, J, R, Blundell, A.Bozio and C. Emmerson (2008). Releasing jobs for the Young? Early retirement and youth unemployment in the United Kingdom, Economics and Social Research Council, Institute for Fiscal Studies, London, IFS working paper no. ISSN: 1742-0415 doi: 10.1920/wp.ifs. 2010.1002.

[2]. Botha, M. G.H. Nieman and J.J. van Vuuren (2006). Evaluating the women entrepreneurship training program: A South African Study. International Indigenous Journal of Entrepreneurship, Advancement, Strategy and Education, ISSN 1177-0317, University of Pretoria, South Africa. Accessed through www.indigenousjournal.com on $5^{\text {th }}$ April 2013

[3]. Bbc.co.uk

http://www.google.co.in/search?q=population + pyramid + of + united + kingdom $+2011 \&$ tbm $=$ isch\&tbo $=u \&$ source $=$ univ\&sa $=X \& e i=H u-$ 1UeiuIsmPrgfix YC4BQ\&ved $=0$ CCsQsAQ\&biw $=1366 \&$ bih $=667$

[4]. Chalmers and Norris (2001). Early Retirement: Does it Lead to Dependency on Income Support? Social Policy Research Centre Uni versity of New South Wales November 2001. ISSN 1446-4179 ISBN 0 7334 1902 X accessed from http://www.sprc.unsw.edu.au/media/File/Report4_01_Early_Retirement.pdf

[5]. Hallberg, D. (2011). Is Early Retirement Encouraged by the Employer? Institutet för Framtidsstudier/Institute for Futures Studies, Stockholm, Sweden. ISSN: 1652-120X ,ISBN: 978-91-85619-82-5 pg 20-22. Accessed through http://www.iffs.se/wpcontent/uploads/2011/06/Arbetsrapport-2011-nr6.pdf

[6]. ILO (2012). Global Employment Trends, International Labor Organization Office-Geneva, May 2012, pg 11, ISBN 978-92-2-126326

[7]. Manpower Group (2012). Youth Employment Challenge and Solutions.pg 5 retrieved on $30^{\text {th }}$ April 2013 from http://www3.weforum.org/docs/Manpower_YouthEmploymentChallengeSolutions_2012.pdf

[8]. Ministry of Foreign Affairs-Denmark (2009). Realising the potential of African Youth. Report of the African Commission, $9^{\text {th }}$ June 2009 accessed through www.netpublikationer.dk/um/9336/index.htm on $6^{\text {th }}$ April 2013

[9]. Muhanna, E. (2007). Conceptual Analysis of the determinants of Entrepreneurship: A South African perspective. Problems and perspectives in Management/ volume 5,issue 1, 2007. Accessed through www.businessperspective.org on $12^{\text {th }}$ January 2013.

[10]. Munjuri, G. (2011). A Survey of the Criteria Used by Commercial Banks in Kenya to Determine Employees to Retrench, Department of Marketing and Management The Catholic University of Eastern Africa. International Journal of Business Administration

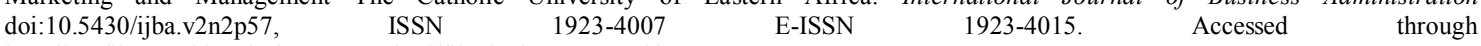
http://profiles.uonbi.ac.ke/mercy gacheri/files/vol 2 no 2.pdf

[11]. Ndedi, A. A. (2009). Entrepreneurship training and job creation in South Africa: are tertiary institutions filling the gap? Journal of contemporary management, vol 6 2009, ISSN 1815-7440, page 463-470.

[12]. SBP Alert (2009).Boosting Youth Employment Through Entrepreneurship-A response to the National Youth Development Agency, An SBP occasional paper, June 2009 , Copyright: (C) SBP 2009, pg 6, accessed through http://www.sbp.org.za/uploads/media/SBP ALERT youth employment june 09.pdf

[13]. S. Mahendra Dev and M. Venkatanarayana (2011) Youth Employment and Unemployment in India, Indira Gandhi Institute of Development Research, pg 29, no WP-2011-009, Mumbai,April 2011 from http://www.igidr.ac.in/pdf/publication/WP-2011-009.pdf

[14]. Tishman, F. S, Van Looy, and S. M.Bruyère (2012). Employer Strategies for Responding to an Aging Workforce, The NTAR Leadership Centre. New Brunswick NJ 080901-732.932.4100X6330, New Jersey. Accessed through http://www.dol.gov/odep/pdf/NTAR Employer Strategies Report.pdf

[15]. Ukpere, W (2011) Globalisation and the challenges of unemployment, income inequality and poverty in Africa. African Journal of Business Management Vol. 5(15), pp. 6072-6084, 4 August, 2011 DOI: 10.5897/AJBM11.905 ISSN 1993-8233 C2011 Academic Journals accessed through https://ujdigispace.uj.ac.za/bitstream/handle/10210/8025/UkpereWI 2011.pdf?sequence=1

[16]. UNESCO (2008). Realising the potential of African youth, www.netpulikationer.dk

WE GREA TLY YCKNOWLEDGE THE SUPPORT OF OUR FAMILIES AAND DEDICATE THIS WORK TO OUR CHILDREN SHALOM, MITCHELL AND DAN. WE THANK GOD THAT IT HAS BEEN POSSIBLE, SO FAR. 